\title{
Analisis Pendapatan Usaha Ayam Broiler Pada Pola dan Skala yang Berbeda di Peternakan Rakyat Kabupaten lumajang
}

\author{
Chicken Broiler Business Income Analysis \\ at Different Scales and Patterns \\ in People's Farms Lumajang
}

\author{
Gilang Nursandhi $^{\# 1}$, Hariadi Subagja ${ }^{\# 2}$, Ujang Suryadi ${ }^{\# 2}$ \\ ${ }^{\# 1}$ Mahasiswa Program Studi Agribisnis - Program Magister Terapan, Politeknik Negeri Jember. \\ ${ }^{\# 2}$ Dosen Program Studi Agribisnis - Program Magister Terapan, Politeknik Negeri Jember.

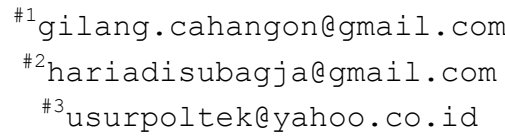

Abstract

This research aims to analyze the difference in the level of revenues savor independent patterns and patterns of partnership at different scales, analyze business patterns and scale venture capable of producing the most income levels are high, analyze the relationship between the pattern and scale of effort against the income level, as well as to analyze the influence of factors of production costs against revenue level savor in Lumajang.Research conducted from 1 July until 31 September 2017 using data at one time production period.Sampling determined deliberately by grouping the respondents based on a combination of the pattern of independent business and partnerships, as well as household business scale, small, and medium. The population that used as many as 60 breeders consisting of 10 samples in each group of a combination of patterns and business scale.Data analysis is an analysis of income and multiple linear regression analysis.Bound variables in this study are the level of revenues savor (Y), with free variables that comprise the cost of day-old chick $\left(X_{1}\right)$, feed $\left(X_{2}\right)$, vaccines, medications, vitamins, and disinfectants $\left(X_{3}\right)$, laborer $\left(X_{4}\right)$, preparation cost of enclosure and fuel $\left(X_{5}\right)$,electricity $\left(X_{6}\right)$, depreciation cost of enclosure and equipment $\left(X_{7}\right)$, and the pattern of effort selected breeders (D) to run his business. The results of the analysis showed that the level of income breeders partnership is higher than a standalone pattern breeder (3.169 rupiahs $>2.801$ rupiahs), whereas small-scale dairy farmers income levels greater than large-scale ranchers and scale house appliances (3.926 rupiahs $>2.564$ rupiahs >2.466 rupiahs). Combinations of patterns of partnership with small-scale yielding the highest income levels compared to the pattern and scale of other businesses. Multiple linear regression analysis results on $F$ testshows that that simultaneously throughout the free variables $\left(X_{1}, X_{2}, X_{3}, X_{4}, X_{5}, X_{6}, X_{7}\right.$, and D) effect significantly to the variable (Y). Results on t-test showed that partially variables $X_{1}, X_{2}$, $X_{3}, X_{4}, X_{7}$ and influential significantly to variable $Y$, whereas the variable $X_{5}, X_{6}$, and $D$ do not affect significantly to the variable $Y$.

Keywords:Income level, Business pattern, and Business scale.

\section{PENDAHULUAN}

Ayam broiler merupakan salah satu komoditas usaha peternakan yang cukup menjanjikan untuk dikembangkan lebih lanjut, karena siklus produksi dan perputaran modal yang lebih cepat dibandingkan komoditas usaha peternakan lainnya.Salah satu parameter yang dapat digunakan untuk mengukur keberhasilan suatu usaha adalah pendapatan. Keberhasilan usaha peternakan ayam broiler ditentukan oleh tiga faktor penting dalam produksi, yaitu : bibit (breeding), pakan (feeding), dan tatakelola (management). Kemampuan peternak dalam mengelola manajemen usaha dan 
mengkombinasikan faktor-faktor produksi akan menentukan pendapatan yang dihasilkan.

Usaha peternakan ayam broiler di Kabupaten Lumajang cukup bervariasi, dan sebagian besar merupakan peternakan rakyat.Peternakan rakyat adalah peternakan yang tidak diwajibkan memiliki ijin usaha, dengan jumlah populasi ternak tidak lebih dari 15.000 ekor ayam broiler untuk setiap periode produksi (Kementan, 2002).Pola yang digunakan untuk menyelenggarakan usaha peternakan ayam broiler dibedakan menjadi dua, yaitupola mandiri dan pola kemitraan. Pola mandiri pada umumnya digunakan oleh peternak yang menyediakan seluruh input produksi usahanya dari modal sendiri, serta memiliki kebebasan untukmengambil keputusan waktu memulai beternak dan memasarkan output produksinya.Pola kemitraan adalah hubungan kerjasama antara peternak sebagai plasma dengan perusahaan sebagai inti menggunakan kontrak perjanjian.Pada pola ini peternak hanya menyediakan kandang, peralatan, dan tenaga kerja, sedangkan perusahaan menyediakan input produksi yang berupa DOC, pakan, vaksin, obat-obatan, dan vitamin. Pengawasan dan pembinaan secara teknis dilakukan oleh perusahaan sekaligus menjamin pemasaran output produksi peternak dengan mengambil hasil panen berdasarkan harga yang telah ditentukan dalam kontrak perjanjian.Skala usaha adalah besaran yang menentukan pendapatan yang diperoleh peternak dari proses produksi usahanya, sehingga perlu diperhitungkan untuk mencapai usaha yang menguntungkan. Skala usaha peternakan ayam broiler dapat dibedakan menurut jumlah tenaga kerja yang digunakan.Idealnya, satu orang tenaga kerja mampu menangani 5.000 ekor ayam broiler jika bekerja di kandang yang menggunakan tempat minum otomatis (Tamalluddin, 2014).

Berdasarkan uraian profil usaha peternakan ayam broiler di Kabupaten Lumajang tersebut, maka sangat menarik untuk dilakukan studi tentang perbedaan antara pola dan skala usaha yangberpengaruh terhadap pendapatan, sehingga peternak dapat mengelola manajemen usaha dan mengkombinasikan faktor-faktor produksi yang dimiliki untuk memperoleh pendapatan yang maksimal.

Tujuan dari penelitian ini adalah : (1)Menganalisaperbedaan pendapatan antara pola mandiri dan pola kemitraan pada skala yang berbeda,(2) Menganalisa pola usaha dan skala usaha yang mampu menghasilkan pendapatan paling tinggi, (3)Menganalisa hubungan antara pola dan skala usaha terhadap pendapatan, serta (4) Menganalisa pengaruh faktor-faktor biaya produksiterhadap pendapatan usaha peternakan ayam broiler di Kabupaten Lumajang.

Manfaat yang diharapkan dalam proses penelitian ini adalah : (1) Menambah khazanah ilmu pengetahuan di bidang manajemen produksi dan operasi serta ekonomi manajerial usaha peternakan ayam broiler, (2) Sumber informasi, pedoman, serta tambahan wawasan dan pengalaman bagi peternak ayam broiler untuk mengendalikan dan mengembangkan usahanya, dan (3) Bahan pertimbangan bagi pemerintah untuk memperbaiki kebijakan sub-sektor peternakan pada masa yang akan datang.

\section{METODE PENELITIAN \\ Lokasi dan Waktu}

Pada penelitian ini dilakukan analisis pendapatan usaha peternakan ayam broiler pada pola dan skala usaha yang berbeda di Kabupaten Lumajang.Penelitian dilakukan menggunakan data pada satu kali periode produksi, dan mulai dilaksanakan pada Tanggal 1 Juli sampai dengan 31 September 2017.

\section{Populasi dan Sampel}

Pengambilan sampel ditentukan secara sengaja (purposive sampling).Lokasi pengambilan sampel adalah kecamatan-kecamatan di Kabupaten Lumajang yang memiliki populasi ternak tertinggi dan dapat mewakili bagian utara, selatan, barat, dan timur.Responden yang dipilih adalah peternak yang memiliki jumlah ayam broiler antara 1.000 sampai 15.000 ekor dalam satu kali periode produksi, dan memiliki pengalaman beternak minimal selama dua tahun. Metode pengambilan sampel dilakukan dengan mengelompokkan responden berdasarkan pola usaha yang dijalankan, yaitu peternak pola mandiri dan peternak pola kemitraan, serta skala usaha yang ditentukan dengan jumlah kepemilikan ternak, yaitu peternak skala rumah tangga, peternak skala kecil, dan peternak skala sedang.Kelompok skala usaha peternak dapat dilihat pada Tabel 1.Populasi yang digunakan dalam penelitian ini adalah 60 peternak yang terdiri dari 10 sampel pada setiap kelompok pola dan skala usaha.Keterangan populasidansampel dapat dilihat pada Tabel 2.

\begin{tabular}{ccc}
\multicolumn{3}{c}{ TABEL 1.KELOMPOK SKALA USAHA PETERNAK. } \\
\hline No. & SKALA USAHA & $\begin{array}{c}\text { JUMLAH TERNAK } \\
\text { (ekor) }\end{array}$ \\
\hline 1 & Rumah tangga & $1.000-5.000$ \\
2 & Kecil & $5.100-10.000$ \\
3 & Sedang & $10.100-15.000$ \\
\hline
\end{tabular}

Sumber : Data diolah, 2017.

\section{Variabel dan Definisi Operasional Variabel}

Variabel terikat (dependent variable) yang digunakan dalam penelitian ini adalah (Y) Pendapatan.Pendapatan merupakan selisih antara penerimaan dengan total biaya yang telah dikeluarkan oleh peternak. Pendapatan dinyatakan dalam satuan rupiah/ekor. 
Gilang Nursandhi, Hariadi Subagja, Ujang Suryadi. Analisis Pendapatan Usaha Ayam Broiler Pada Pola dan Skala yang Berbeda di Peternakan Rakyat Kabupaten lumajang

Variabel bebas (independent variable) yang digunakan dalam penelitian ini adalah biaya produksi yang terdiri dari biaya :

$\left(\mathrm{X}_{1}\right)$ DOC, adalah bibit ayam berumur 1 hari yang dipelihara dalam satu kali periode produksi, biayanya diukur dalam satuan rupiah/ekor.
$\left(\mathrm{X}_{2}\right)$ Pakan, adalah banyaknya pakan yang dihabiskan dalam satu kali periode produksi, biayanya diukur dalam satuan rupiah/ekor.

TABEL 2.POPULASI DAN SAMPEL.

\begin{tabular}{|c|c|c|c|c|c|c|c|c|c|}
\hline \multirow{2}{*}{ No. } & \multirow{2}{*}{ KECAMATAN } & \multirow{2}{*}{$\begin{array}{c}\text { KABUPATEN } \\
\text { LUMAJANG } \\
\text { (bagian) }\end{array}$} & \multirow{2}{*}{$\begin{array}{c}\text { JUMLAH } \\
\text { SAMPEL } \\
\text { (orang) } \\
\end{array}$} & \multicolumn{6}{|c|}{ POLA DAN SKALA USAHA } \\
\hline & & & & MR & MK & MS & KR & KK & $\mathbf{K S}$ \\
\hline 1 & Senduro & Barat & 6 & 0 & 1 & 2 & 0 & 1 & 2 \\
\hline 2 & Sumbersuko & Timur & 6 & 0 & 1 & 2 & 0 & 1 & 2 \\
\hline 3 & Kunir & Timur & 6 & 0 & 1 & 2 & 0 & 1 & 2 \\
\hline 4 & Tempeh & Timur & 6 & 0 & 1 & 2 & 0 & 1 & 2 \\
\hline 5 & Pasirian & Selatan & 6 & 0 & 2 & 1 & 0 & 2 & 1 \\
\hline 6 & Pronojiwo & Selatan & 6 & 1 & 1 & 1 & 1 & 1 & 1 \\
\hline 7 & Randuagung & Utara & 4 & 1 & 1 & 0 & 1 & 1 & 0 \\
\hline 8 & Pasrujambe & Barat & 4 & 1 & 1 & 0 & 1 & 1 & 0 \\
\hline 9 & Kedungjajang & Utara & 4 & 1 & 1 & 0 & 1 & 1 & 0 \\
\hline 10 & Gucialit & Barat & 4 & 2 & 0 & 0 & 2 & 0 & 0 \\
\hline 11 & Candipuro & Selatan & 4 & 2 & 0 & 0 & 2 & 0 & 0 \\
\hline 12 & Lumajang & Utara & 4 & 2 & 0 & 0 & 2 & 0 & 0 \\
\hline \multicolumn{3}{|c|}{ TOTAL POPULASI } & 60 & 10 & 10 & 10 & 10 & 10 & 10 \\
\hline
\end{tabular}

Keterangan : MR (peternak pola mandiri skala rumah tangga), MK (peternak pola mandiri skala kecil), MS (peternak pola mandiri skala sedang), KR (peternak pola kemitraan skala rumah tangga), KK (peternak pola kemitraan skala kecil), KS (peternak pola kemitraan skala sedang).

Sumber : Data diolah, 2017.

$\left(\mathrm{X}_{3}\right)$ Vaksin, obat, vitamin, dan desinfektan, adalah banyaknya vaksin, obat, vitamin, dan desinfektan yang dihabiskan dalam satu kali periode produksi, biayanya diukur dalam satuan rupiah/ekor.

$\left(\mathrm{X}_{4}\right)$ Tenaga kerja, adalah banyaknya tenaga kerja yang digunakan dalam proses produksi selama satu periode pemeliharaan, biayanya dihitung dalam satuan rupiah/ekor.

$\left(\mathrm{X}_{5}\right)$ Persiapan kandang dan bahan bakar, adalah banyaknya sekam, koran bekas, dan bahan bakar yang digunakan untuk operasional fase brooding pada saat ayam berumur 1 sampai 14 hari (periode starter), biayanya dihitung dalam satuan rupiah/ekor. $\left(\mathrm{X}_{6}\right)$ Listrik, adalah banyaknya listrik yang digunakan dalam proses produksi selama satu periode pemeliharaan, biayanya dihitung dalam satuan rupiah/ekor.

$\left(\mathrm{X}_{7}\right)$ Penyusutan kandang dan peralatan, adalah biaya yang dikeluarkan untuk berkurangnya nilai dan kapasitas kandang beserta peralatan selama satu periode pemeliharaan, biayanya dinyatakan dalam satuan rupiah/ekor.

(D) Pola usaha, adalah variabel dummy yang menggambarkan pola usaha yang dipilih peternak untuk menjalankan usahanya. Pola usaha terbagi menjadi dua, yaitu pola mandiri yang dinyatakan dengan notasi (0)danpola kemitraan yang dinyatakan dengan notasi (1).

Jenis dan Prosedur Pengumpulan Data

Jenis data yang digunakan adalah data primerdan data sekunder.Data primer adalah data yang diperoleh langsung dari peternak responden. Prosedur pengumpulan data primer terdiri dari beberapa cara, yaitu observasi dan wawancara menggunakan kuisioner, serta dokumentasi.

Data sekunder adalah data yang diperoleh secara tidak langsung dari hasil laporan instansi atau lembaga, dan penelitian-penelitian yang terkait dengan penelitian ini. Prosedur pengumpulan data sekunder dilakukan dengan cara mengutip data-data yang bersumber dari BPS Kabupaten Lumajang dan Dinas Peternakan Kabupaten Lumajang, serta melakukan studi literatur pada beberapa buku, jurnal penelitian, dan referensi internet.

\section{Analisis Data}

\section{a. Analisis Pendapatan}

Pendapatan

$$
\pi=T R-T C
$$

Keterangan :

$$
\begin{array}{ll}
\pi & : \text { Pendapatan } \\
\text { TR } & : \text { Total Revenue (total penerimaan) } \\
\text { TC } & : \text { Total Cost (total biaya) }
\end{array}
$$

\section{b. Analisis Regresi Linear Berganda}

Sebelum dilakukan analisis regresi linier berganda, terlebih dahulu dilakukan uji asumsi klasik yang meliputi normalitas, multikolinieritas, dan heterokedastisitas.Jika hasil yang diperoleh memenuhi persyaratan, maka langkah selanjutnya dapat dilakukan.Biaya-biaya produksi dan pola usaha yang berpengaruh terhadap pendapatan usaha peternakan ayam broiler di Kabupaten Lumajang diuji dengan menggunakan fungsi Cobb-Douglas 
melalui analisis regresi berganda dengan alat bantuStatistical Package for the Social Sciences (SPSS).Fungsi Cobb-Douglas dapat dituliskan sebagai berikut :

$$
\begin{aligned}
\mathrm{Y}=\mathrm{a}+\mathrm{b} 1 \mathrm{X} 1+\mathrm{b} 2 \mathrm{X} 2+\mathrm{b} 3 \mathrm{X} 3+\mathrm{b} 4 \mathrm{X} 4+\mathrm{b} 5 \mathrm{X} 5 \\
+\mathrm{b} 6 \mathrm{X} 6+\mathrm{b} 7 \mathrm{X} 7+\mathrm{dD}+\mathrm{ei}
\end{aligned}
$$

Kemudian fungsi tersebut ditransformasikan ke dalam bentuk linier berganda dengan cara dilogaritmakan (Ln), tujuannya adalah untuk memudahkan pendugaan dan mendekatkan skala data. Bentuk logaritma dari fungsi di atas adalah sebagai berikut :

$$
\begin{aligned}
& \operatorname{LnY}=\operatorname{Ln} a+b 1 \operatorname{LnX} 1+b 2 \operatorname{LnX} 2+b 3 \operatorname{LnX} 3 \\
& + \text { b4LnX4 + b5LnX5 + b6LnX6 } \\
& + \text { b7 LnX7 + dD + ei }
\end{aligned}
$$

Keterangan :

Y $\quad=$ Pendapatan

a $\quad=$ Konstanta

$\mathrm{b} ; \mathrm{d}=$ Koefisien regresi

$\mathrm{X}_{1} \quad=$ Biaya DOC

$\mathrm{X}_{2} \quad=$ Biaya pakan

$\mathrm{X}_{3} \quad=$ Biaya vaksin, obat, vitamin, dandesinfektan

$\mathrm{X}_{4} \quad=$ Biaya tenaga kerja

$\mathrm{X}_{5} \quad=$ Biaya persiapan kandang dan bahan bakar

$\mathrm{X}_{6} \quad=$ Biaya listrik

$\mathrm{X}_{7} \quad=$ Biaya penyusutan kandang dan peralatan

$\mathrm{D} \quad=$ Pola usaha (variabel dummy)

ei $\quad=$ Faktor-faktor pengganggu

Setelah koefisien masing-masing variabel diperoleh, selanjutnya dilakukan uji statistik.Uji statistik yang dilakukan meliputi koefisien determinasi, uji F, dan uji t. Koefisien determinasi $\left(\mathrm{R}^{2}\right)$ digunakan untuk menunjukkan sampai seberapa besar variansi variabel terikat dapat dijelaskan oleh variansi dari variabel bebas.

Uji pengaruh dari variabel bebas terhadap variabel terikat dilakukan dengan uji $\mathrm{F}$ dan uji t yang terintegrasikan dalam analisis regresi linear berganda.Uji $F$ dan uji t digunakan untuk menguji pengaruh secara simultan dan secara parsial biayabiaya produksi dan pola usaha yang digunakan oleh peternak terhadap pendapatan usaha ayam broiler.

\section{HASIL DAN PEMBAHASAN Analisis Pendapatan}

Struktur biaya, penerimaan, dan pendapatan rataratausaha peternakan ayam broiler pada pola dan skala usaha yang berbeda di Kabupaten Lumajang dapat dilihat pada Tabel 3 dan 4.Hasil perhitungan $\mathrm{R} / \mathrm{C}$ rasio dan profit margin menunjukkan bahwa, pola kemitraan lebih menguntungkan dibandingkan pola mandiri.Skala usaha yang paling menguntungkan adalah skala kecil.Rata-rata nilai $\mathrm{R} / \mathrm{C}$ rasio peternak pada seluruh pola dan skala usaha adalah lebih dari $1(\mathrm{R} / \mathrm{C}>1)$.Hal ini berarti bahwa, usaha peternakan ayam broiler di Kabupaten Lumajang menguntungkan, namun pencapaian tersebut menggambarkan bahwa usaha peternakan ayam broiler rawan dengan maksud tingkat resiko dan ketidakpastiannya besar.

Berdasarkan Tabel 3 diperoleh bahwa, pendapatan peternak pola kemitraan lebih tinggi dibandingkan peternak pola mandiri.Perbedaan pendapatan antara kedua pola usaha tersebut dipengaruhi oleh produktivitas ternak dan harga panen. Angka deplesi peternak pola kemitraan lebih kecil dibandingkan peternak pola mandiri $(2,13 \%$ < $4,60 \%$ ), karena peternak pola kemitraan didukung oleh pelayanan tenaga ahli yang disediakan perusahaan inti, sehingga penanganan kegiatan pemeliharaan menjadi lebih tepat. Harga panen peternak pola kemitraan lebih besar dibandingkan peternak pola mandiri (16.938 rupiah/kg > 16.768 rupiah/kg), karena peternak pola kemitraan telah mendapat kepastian harga jual pada kontrak perjanjian yang telah disepakati dengan perusahaan inti, sedangkan harga jual peternak pola mandiri bergantung pada situasi pasar. Hal ini sesuai dengan hasil penelitian Suwarta, dkk., (2009) yang menyimpulkan bahwa, produktivitas usaha ternak ayam broiler peternak kemitraan lebih besar daripada peternak mandiri.

Berdasarkan Tabel 4 diperoleh bahwa, pendapatan peternak skala kecil lebih tinggi dibandingkan peternak skala rumah tangga dan peternak skala sedang.Perbedaan pendapatan antara ketiga skala usaha tersebut dipengaruhi oleh faktor tenaga kerja yang berperan sebagai pelaksana kegiatan pemeliharaan.Tenaga kerja yang digunakan oleh peternak skala rumah tangga adalah anggota keluarga dan pemilik usaha tersebut.Banyaknya anggota keluarga yang ikut bekerja dan belum tentu memiliki keterampilan dalam menangani ternak, berdampak pada pelaksanaan kegiatan pemeliharaan yang kurang efektif. Hal yang sama juga terjadi pada peternak skala sedang. Jumlah tenaga kerja yang digunakan oleh peternak skala sedang dengan populasi ayam broiler antara 10.100 sampai 15.000 ekor adalah empat orang, sedangkan idealnya adalah tiga orang dengan perbandingan satu orang mampu menangani 5.000 ekor ayam. Jumlah tenaga kerja yang berlebihan menyebabkan penanganan kegiatan pemeliharaan menjadi kurang efisien.Hal tersebut juga mengakibatkan aktifitas ayam di dalam kandang menjadi terganggu, sehingga ayam menjadi stres dan produksinya menurun (Tamalluddin 2014).

\section{Uji Asumsi Klasik}

\section{Uji Normalitas}

Uji normalitas bertujuan untuk mengetahui apakah variabel yang digunakan dalam analisis pendapatan berdistribusi normal atau tidak (Ghozali, 2016).Uji normalitas dilakukandengan melihat Kurva P-Plot Ln Pendapatan.Hasil uji normalitas dapat dilihat pada Gambar 1.Pada Gambar 1 menunjukkan bahwa, titik-titik data terdistribusi dan menyebar mengikuti garis diagonal kurva. Menurut 
Gilang Nursandhi, Hariadi Subagja, Ujang Suryadi. Analisis Pendapatan Usaha Ayam Broiler Pada Pola dan Skala yang Berbeda di Peternakan Rakyat Kabupaten lumajang

Ghozali (2016), jika data menyebar di sekitar garis diagonal dan mengikuti arah garis diagonal, maka model tersebut memenuhi asumsi normalitas.

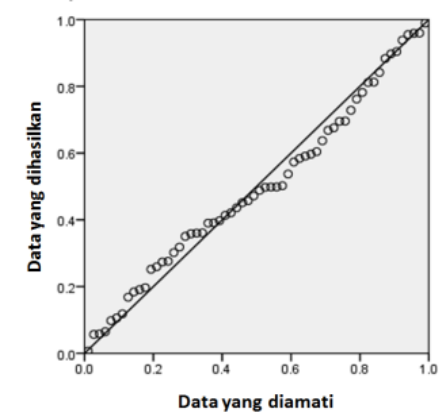

Gambar 1.Kurva P-Plot Ln Pendapatan.

Tabel 3.Hasil Usaha Peternakan Ayam Broiler Pada Pola UsaHa yang Berbeda.

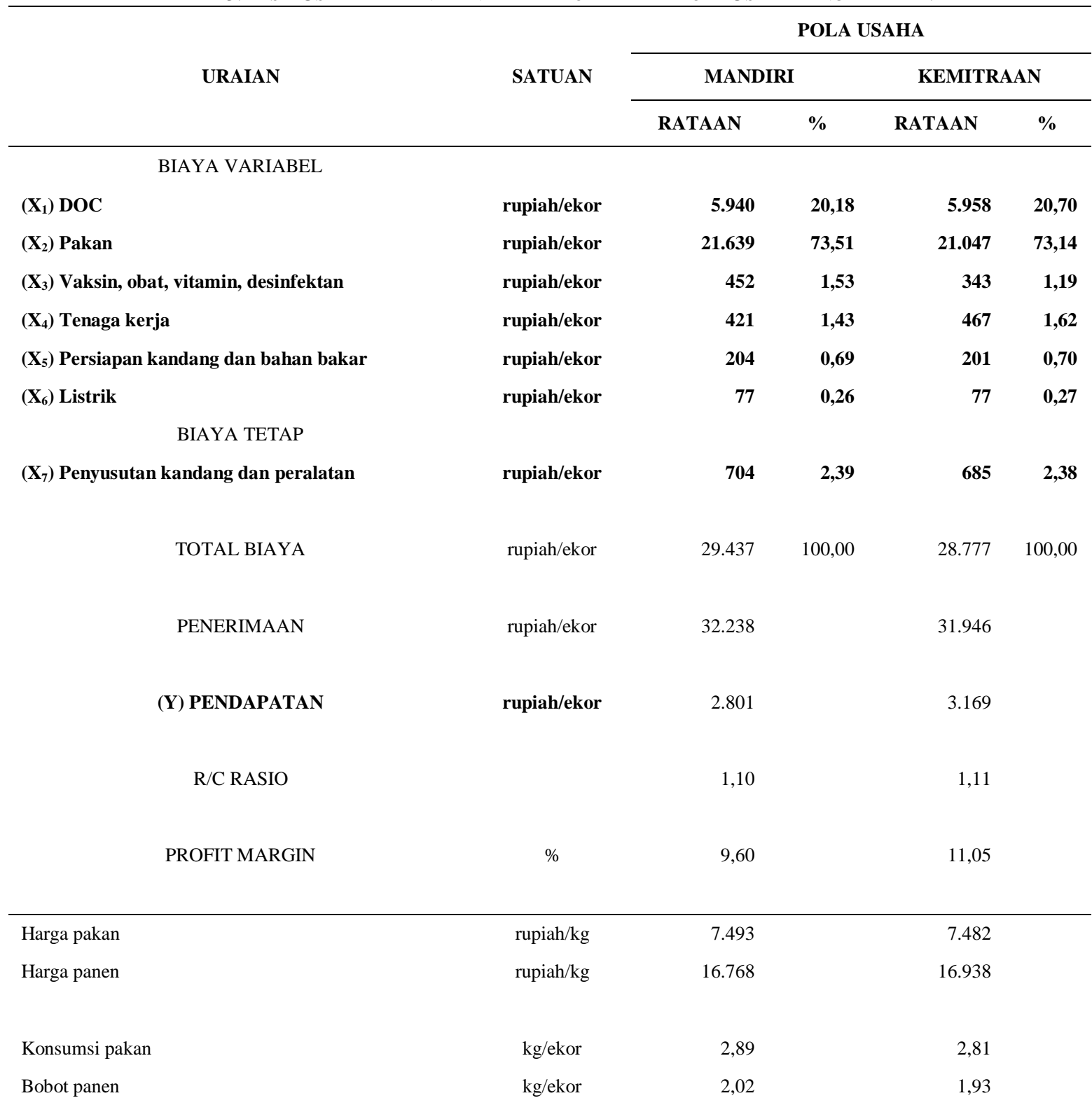


Jurnal Ilmiah INOVASI, Vol. 18 No. 1 Edisi Januari April 2018, ISSN 1411-5549

$\begin{array}{lccr}\text { Deplesi } & \% & 4,60 & 2,13 \\ \text { Daya hidup } & \% & 95,40 & 97,87 \\ \text { FCR } & & 1,51 & 1,49 \\ \text { Umur panen } & \text { Hari } & 34,2 & 33,3 \\ & & 375 & 379\end{array}$

Tabel 4.Hasil Usaha Peternakan Ayam Broiler Pada Skala Usaha Yang Berbeda.

\begin{tabular}{|c|c|c|c|c|c|c|c|}
\hline \multirow{3}{*}{ URAIAN } & \multirow{3}{*}{ SATUAN } & \multicolumn{6}{|c|}{ SKALA USAHA } \\
\hline & & \multicolumn{2}{|c|}{ RUMAH TANGGA } & \multicolumn{2}{|c|}{ KECIL } & \multicolumn{2}{|c|}{ SEDANG } \\
\hline & & RATAAN & $\%$ & RATAAN & $\%$ & RATAAN & $\%$ \\
\hline \multicolumn{8}{|l|}{ BIAYA VARIABEL } \\
\hline$\left(\mathrm{X}_{1}\right)$ DOC & rupiah/ekor & 5.961 & 20,45 & 5.920 & 20,38 & 5.966 & $\begin{array}{r}20,4 \\
9\end{array}$ \\
\hline$\left(\mathbf{X}_{2}\right)$ Pakan & rupiah/ekor & 21.314 & 73,12 & 21.316 & 73,35 & 21.400 & $\begin{array}{r}73,5 \\
0\end{array}$ \\
\hline$\left(X_{3}\right)$ Vaksin, obat, vitamin, desinfektan & rupiah/ekor & 404 & 1,39 & 399 & 1,37 & 389 & 1,33 \\
\hline$\left(\mathbf{X}_{4}\right)$ Tenaga kerja & rupiah/ekor & 460 & 1,58 & 460 & 1,58 & 412 & 1,41 \\
\hline$\left(\mathbf{X}_{5}\right)$ Persiapan kandang dan bahan bakar & rupiah/ekor & 202 & 0,69 & 204 & $\mathbf{0 , 7 0}$ & 201 & 0,69 \\
\hline$\left(\mathbf{X}_{6}\right)$ Listrik & rupiah/ekor & 77 & 0,26 & 78 & 0,27 & 76 & 0,26 \\
\hline \multicolumn{8}{|l|}{ BIAYA TETAP } \\
\hline$\left(\mathbf{X}_{7}\right)$ Penyusutan kandang dan peralatan & rupiah/ekor & 728 & 2,50 & 683 & 2,35 & 672 & 2,31 \\
\hline TOTAL BIAYA & rupiah/ekor & 29.146 & 100,00 & 29.060 & 100,00 & 29.115 & $\begin{array}{r}100 \\
00\end{array}$ \\
\hline PENERIMAAN & rupiah/ekor & 31.612 & & 32.986 & & 31.679 & \\
\hline (Y) PENDAPATAN & rupiah/ekor & 2.466 & & 3.926 & & 2.564 & \\
\hline R/C RASIO & & 1,09 & & 1,14 & & 1,09 & \\
\hline PROFIT MARGIN & $\%$ & 8,56 & & 13,62 & & 8,81 & \\
\hline Harga pakan & rupiah $/ \mathrm{kg}$ & 7.520 & & 7.462 & & 7.481 & \\
\hline Harga panen & rupiah $/ \mathrm{kg}$ & 16.923 & & 16.940 & & 16.698 & \\
\hline Konsumsi pakan & $\mathrm{kg} / \mathrm{ekor}$ & 2,84 & & 2,86 & & 2,86 & \\
\hline Bobot panen & $\mathrm{kg} / \mathrm{ekor}$ & 1,95 & & 2,02 & & 1,95 & \\
\hline
\end{tabular}


Gilang Nursandhi, Hariadi Subagja, Ujang Suryadi. Analisis Pendapatan Usaha Ayam Broiler Pada Pola dan Skala yang Berbeda di Peternakan Rakyat Kabupaten lumajang

\begin{tabular}{|c|c|c|c|c|}
\hline Deplesi & $\%$ & 3,90 & 3,47 & 2,73 \\
\hline Daya hidup & $\%$ & 96,10 & 96,53 & 97,27 \\
\hline FCR & & 1,52 & 1,47 & 1,51 \\
\hline Umur panen & Hari & 33,5 & 34,3 & 33,6 \\
\hline Indeks Performa (IP) & & 368 & 388 & 375 \\
\hline
\end{tabular}

Sumber : Data diolah, 2018.

\section{Uji Multikolinieritas}

Uji multikolinieritas dilakukan dengan melihat nilai TOL (tolerance) dan VIF (variance inflation factor) pada hasil analisis regresi menggunakan program SPSS. Nilai cut-off yang umum digunakan untuk menunjukkan multikolinieritas adalah nilai TOL $\geq 0,10$ atau sama dengan nilai VIF $\leq 10$ (Ghozali, 2016). Hasil uji multikolinieritas disajikan pada Tabel 5. Berdasarkan Tabel 5 dapat dilihat bahwa masing-masing variabel bebas memiliki nilai TOL $\geq 0,10$ dan nilai $\mathrm{VIF} \leq 10$, sehingga tidak terjadi multikolinieritas antar variabel bebas dalam model regresi yang digunakan.

TABel 5. Hasil Uji MultikOlinieRitas.

\begin{tabular}{lcc}
\hline & MODEL & \multicolumn{2}{c}{ Collinearity Statistics } \\
\cline { 2 - 3 }$($ Constant $)$ & TOL & VIF \\
$\left(X_{1}\right)$ DOC & 0,300 & 3,337 \\
$\left(X_{2}\right)$ Pakan & 0,380 & 2,633 \\
$\left(X_{3}\right)$ Vaksin, obat, vitamin, desinfektan & 0,505 & 1,982 \\
$\left(X_{4}\right)$ Tenaga kerja & 0,390 & 2,567 \\
$\left(X_{5}\right)$ Persiapan kandang dan bahan bakar & 0,456 & 2,192 \\
$\left(X_{6}\right)$ Listrik & 0,540 & 1,853 \\
$\left(X_{7}\right)$ Penyusutan kandang dan peralatan & 0,456 & 2,191 \\
(Dummy) Pola usaha & 0,797 & 1,255 \\
\hline Sumber Data diolah, 2018 & &
\end{tabular}

\section{Uji Heterokedastisitas}

Uji heterokedastisitas dapat dilakukan dengan cara melihat sebaran titik-titik data melalui scatter plot. Scatter plot merupakan grafik yang menggambarkan hubungan antara *ZPRED sebagai variabel terikat dan *SRESID sebagai residualnya (Dewi dan Mulyo, 2015). Scatter plot dapat dilihat pada Gambar 2. Pada Gambar 2 dapat dilihat bahwa titik-titik data melebar dan menyebar secara acak baik di atas maupun di bawah angka 0 pada sumbu Y, sehingga dapat disimpulkan bahwa tidak terdapat heterokedastisitas pada data.

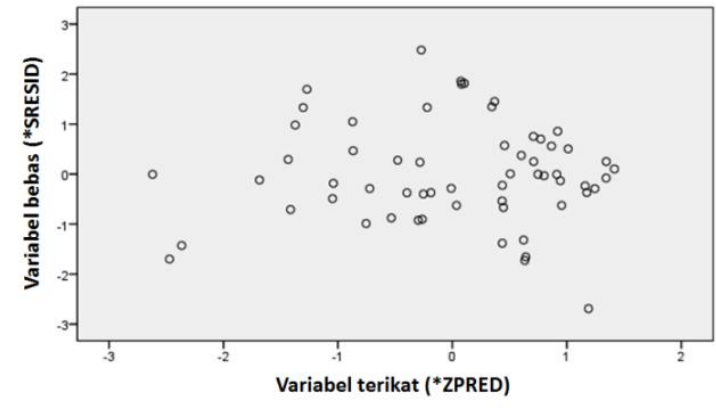

Gambar 2. Scatter Plot Ln Pendapatan.

\section{Analisis Regresi Linier Berganda}

Hasil analisis regresi faktor-faktor yang mempengaruhi pendapatan usaha peternakan ayam broiler di Kabupaten Lumajang dapat dilihat pada Tabel 6. 
TABEL 6.HASIL ANALISIS REGRESI LINIER BERGANDA.

\begin{tabular}{|c|c|c|}
\hline VARIABEL & $\begin{array}{c}\text { KOEFISIEN } \\
\text { REGRESI } \\
\end{array}$ & Sig. $t$ \\
\hline$($ Constant $)$ & 3,429 & 0,026 \\
\hline$\left(\mathrm{X}_{1}\right) \mathrm{DOC}$ & 0,378 & $0,000 *$ \\
\hline$\left(\mathrm{X}_{2}\right)$ Pakan & 0,197 & $0,035 *$ \\
\hline$\left(\mathrm{X}_{3}\right)$ Vaksin, obat, vitamin, desinfektan & $-0,165$ & $0,016^{*}$ \\
\hline$\left(\mathrm{X}_{4}\right)$ Tenaga kerja & 0,217 & $0,043 *$ \\
\hline$\left(\mathrm{X}_{5}\right)$ Persiapan kandang dan bahan bakar & 0,025 & $0,793^{\mathrm{NS}}$ \\
\hline$\left(\mathrm{X}_{6}\right)$ Listrik & 0,082 & $0,376^{\text {NS }}$ \\
\hline$\left(\mathrm{X}_{7}\right)$ Penyusutan kandang dan peralatan & 0,223 & $0,032 *$ \\
\hline (D) Pola usaha & 0,082 & $0,500^{\mathrm{NS}}$ \\
\hline Adjusted $\mathrm{R}^{2}$ & 0,717 & \\
\hline Sig. F & 0,000 & \\
\hline $\mathrm{N}$ & 60 & \\
\hline
\end{tabular}

Keterangan : (*) Signifikansi pada $\alpha=0,05 ;\left({ }^{\mathrm{NS}}\right)$ Non-signifikan.

Sumber : Data diolah, 2018.

Berdasarkan Tabel 6, maka diperoleh fungsi atau persamaan sebagai berikut :

LnY = Ln 3,429 + 0,378 LnX1 + 0,197 LnX2 0,165 LnX3 + 0,217 LnX4 + 0,025 LnX5 + 0,082 LnX6 + 0,223 LnX7 + 0,082 D

\section{Koefisien Determinasi}

Berdasarkan hasil analisis statistik diperoleh nilai koefisien determinasi (adjusted $\mathrm{R}^{2}$ ) sebesar 0,717. Nilai tersebut menunjukkan $71,7 \%$ dari variabel terikat yaitu (Y) Pendapatan usaha peternakan ayam broiler dapat dijelaskan oleh variabel bebas yang meliputi biaya $\left(\mathrm{X}_{1}\right)$ DOC, $\left(\mathrm{X}_{2}\right)$ Pakan, $\left(\mathrm{X}_{3}\right)$ Vaksin, obat, vitamin, dan desinfektan, $\left(\mathrm{X}_{4}\right)$ Tenaga kerja, $\left(\mathrm{X}_{5}\right)$ Persiapan kandang dan bahan bakar, $\left(\mathrm{X}_{6}\right)$ Listrik, $\left(\mathrm{X}_{7}\right)$ Penyusutan kandang dan peralatan, serta (D) Pola usaha. Sisanya sebesar 28,3\% dijelaskan oleh variabel bebas lain yang tidak diteliti. Uji F

Berdasarkan hasil analisis statistik diperoleh bahwa, nilai Sig. F lebih kecil dibandingkan nilai Sig. $\alpha(0,000<0,05)$. Sehingga dapat disimpulkan bahwa, secara bersama-sama biaya $\left(\mathrm{X}_{1}\right)$ DOC, $\left(\mathrm{X}_{2}\right)$ Pakan, $\left(\mathrm{X}_{3}\right)$ Vaksin, obat, vitamin, dan desinfektan, $\left(\mathrm{X}_{4}\right)$ Tenaga kerja, $\left(\mathrm{X}_{5}\right)$ Persiapan kandang dan bahan bakar, $\left(\mathrm{X}_{6}\right)$ Listrik, $\left(\mathrm{X}_{7}\right)$ Penyusutan kandang dan peralatan, serta (D) Pola usaha berpengaruh signifikan terhadap (Y) Pendapatan usaha peternakan ayam broiler.

Uji t

Biaya DOC $\left(\mathrm{X}_{1}\right)$, diperoleh nilai Sig. t lebih kecil dibandingkan nilai Sig. $\alpha(0,000<0,05)$. Artinya biaya DOC berpengaruh signifikan terhadap pendapatan usaha peternakan ayam broiler.

Biaya pakan $\left(\mathrm{X}_{2}\right)$, diperoleh nilai Sig. $\mathrm{t}$ lebih kecil dibandingkan nilai Sig. $\alpha \quad(0,035<$ $0,05)$.Artinya biaya pakan berpengaruh signifikan terhadap pendapatan usaha peternakan ayam broiler.

Biaya vaksin, obat, vitamin, dan desinfektan $\left(\mathrm{X}_{3}\right)$, diperoleh nilai Sig. $\mathrm{t}$ lebih kecil dibandingkan Sig. $\alpha$ $(0,016<0,05)$. Artinya biaya vaksin, obat, vitamin, dan desinfektan berpengaruh signifikan terhadap pendapatan usaha peternakan ayam broiler.
Biaya tenaga $\operatorname{kerja}\left(\mathrm{X}_{4}\right)$, diperoleh nilai Sig. $\mathrm{t}$ lebih kecil dibandingkan Sig. $\alpha \quad(0,043<$ 0,05).Artinya biaya tenaga kerja berpengaruh signifikan terhadap pendapatan usaha peternakan ayam broiler.

Biaya persiapan kandang dan bahan bakar $\left(\mathrm{X}_{5}\right)$, diperoleh nilai Sig. $t$ lebih besar dibandingkan Sig. $\alpha$ $(0,793>0,05)$. Artinya biaya persiapan kandang dan bahan bakar tidak berpengaruh signifikan terhadap pendapatan usaha peternakan ayam broiler.

Biaya listrik $\left(\mathrm{X}_{6}\right)$, diperoleh nilai Sig. t lebih besar dibandingkan Sig. $\alpha(0,376>0,05)$. Artinya biaya listrik tidak berpengaruh signifikan terhadap pendapatan usaha peternakan ayam broiler.

Biaya penyusutan kandang dan peralatan $\left(\mathrm{X}_{7}\right)$,diperoleh nilai Sig. $\mathrm{t}$ lebih kecil dibandingkan Sig. $\alpha(0,032<0,05)$. Artinya biaya penyusutan kandang dan peralatan berpengaruh signifikan terhadap pendapatan usaha peternakan ayam broiler.

Hasil analisis variabel dummy yaitu pola usaha(D), diperoleh nilai Sig. $\mathrm{t}$ lebih besar dibandingkan Sig. $\alpha(0,500>0,05)$. Artinya pola usaha yang digunakan peternak baik pola mandiri maupun pola kemitraan tidak mempengaruhi pendapatan.

\section{KESIMPULAN}

1. Terdapat perbedaan pendapatan antara usaha peternakan ayam broiler pola mandiri dan pola kemitraan pada skala yang berbeda di Kabupaten Lumajang. Pendapatan yang dihasilkan pola kemitraan sebesar 3.169 rupiah/ekor lebih tinggi daripada pola mandiri sebesar 2.801 rupiah/ekor.

2. Pendapatan yang dihasilkan oleh peternak skala kecil sebesar 3.926 rupiah/ekor lebih tinggi daripada peternak skala sedang sebesar 2.564 rupiah/ekor dan peternak skala rumah tangga sebesar 2.466 rupiah/ekor, baik pola mandiri maupun pola kemitraan pada usaha peternakan ayam broiler di Kabupaten Lumajang. 
Gilang Nursandhi, Hariadi Subagja, Ujang Suryadi. Analisis Pendapatan Usaha Ayam Broiler Pada Pola dan Skala yang Berbeda di Peternakan Rakyat Kabupaten lumajang

3. Terdapat hubungan antara pola dan skala usaha terhadap pendapatan pada peternakan ayam broiler di Kabupaten Lumajang. Kombinasi antara pola kemitraan dengan skala kecil menghasilkanpendapatan paling tinggi dibandingkan kombinasi pola dan skala usaha yang lain.

4. Faktor-faktor biaya produksi yang meliputi biaya : $\left(\mathrm{X}_{1}\right)$ DOC, $\left(\mathrm{X}_{2}\right)$ Pakan, $\left(\mathrm{X}_{3}\right)$ Vaksin, obat, vitamin, dan desinfektan, $\left(\mathrm{X}_{4}\right)$ Tenaga kerja, $\left(\mathrm{X}_{5}\right)$ Persiapan kandang dan bahan bakar, $\left(\mathrm{X}_{6}\right)$ Listrik, $\left(\mathrm{X}_{7}\right)$ Penyusutan kandang dan peralatan, serta (D) Pola usaha berpengaruh signifikan secara simultan terhadap (Y) Pendapatan usaha peternakan ayam broiler di Kabupaten Lumajang.Biaya $\left(\mathrm{X}_{1}\right)$ DOC, $\left(\mathrm{X}_{2}\right)$ Pakan, $\left(\mathrm{X}_{3}\right)$ Vaksin, obat, vitamin, dan desinfektan, $\left(\mathrm{X}_{4}\right)$ Tenaga kerja,serta $\left(\mathrm{X}_{7}\right)$ Penyusutan kandang dan peralatan berpengaruh signifikan secara parsial terhadap (Y) Pendapatan usaha peternakan ayam broiler di Kabupaten Lumajang, sedangkan biaya $\left(\mathrm{X}_{5}\right)$ Persiapan kandang dan bahan bakar, $\left(\mathrm{X}_{6}\right)$ Listrik, serta (D) Pola usaha tidak berpengaruh signifikansecara parsial terhadap (Y) Pendapatan usaha peternakan ayam broiler di Kabupaten Lumajang.

\section{UCAPAN TERIMA KASIH}

Penulis menyampaikan terima kasih kepada Kementerian Pendidikan dan Kebudayaan yang telah memberikan Beasiswa Unggulan Pendidikan S-2 Tahun 2015 di Program Studi Agribisnis - Program Magister Terapan, Politeknik Negeri Jember.

\section{DAFTAR PUSTAKA}

[1] Bahari D. I., Fanani Z., Nugroho B. A., 2011. Analisis Struktur Biaya dan Perbedaan Pendapatan Usaha Ternak Ayam Ras Pedaging pada Pola dan Skala Usaha Ternak yang berbeda di Kota Kendari Provinsi Sulawesi Tenggara. Jurnal Ternak Tropika. Vol.13 No.1 : 35-46, 2012. Fakultas Peternakan Universitas Brawijaya, Malang.

[2] Dewi \& Mulyo, 2015.Analisis Produksi Budidaya Ikan Lele (Clarias Gariepinus) : Pendekatan Fungsi Produksi Cobb-Douglas. JurnalPerikanan. Vol.17 No.2 : 54-60, 2016.

[3] Ghozali I., 2016. Aplikasi Analisis Multivariete dengan Program IBM SPSS 23. Badan Penerbit Universitas Diponegoro, Semarang.

[4] Kementan, 2002.Prospek dan ArahPengembangan Agribisnis Unggas.Badan Penelitian danPengembangan Pertanian.Kementerian Pertanian, Jakarta.

[5] Soekartawi. 2003. Agribisnis, Teori, dan Aplikasinya.PT. Gajah Grafindo Persada, Jakarta.

[6] Suwarta, Irham, dan Hartono, 2010. Efektifitas Pola Kemitraan Inti-Plasma dan Produktivitas Usaha Ternak Ayam Broiler Peternak Plasma dan Mandiri serta
Faktor yang Mempengaruhi di Kabupaten Sleman. JSEP. Vol.4 No.1, 2011.

[7] Tamalluddin F., 2014. Pemeliharaan Ayam Broiler.http://www.ternakpertama.com/2014/12/pemelih araan-ayam-broiler-mandiri-atau-kemitraan.html.

[8] Wuryanto, Ichwani, dan Kadarso, 2015. Analisis Produksi Usaha Peternakan Ayam Pedaging di Kabupaten Sleman. Jurnal Agros. Vol.17 No.1 : 71-80, 2016.

9] Yunus R., 2009. Analisis Efisiensi Produksi Usaha Peternakan Ayam Ras Pedaging Pola Kemitraan dan Mandiri di Kota Palu Provinsi Sulawesi Tengah.Tesis S2. Program Pascasarjana Universitas Diponegoro, Semarang. 